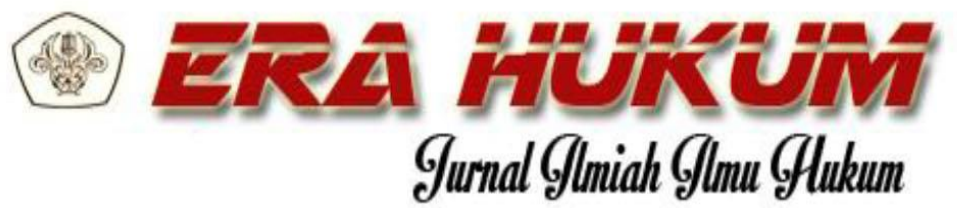

Volume 17, No. 1, Juni 2019

ISSN 0854-8242 | e-ISSN 2581-0359

Fakultas Hukum - Universitas Tarumanagara open Access at: wwwjournal,untar.ac.id/index.php/hukum

Era Hukum - Jurnal Imiah Ilmu Hukum is licensed under Creative Commons Attribution 4.0 International License, which allows otherwriters to use, distribute, and/or build upon this article, as long as the original work is propery cited.

\title{
PENERAPAN DIVERSI TERHADAP ANAK YANG BERHADAPAN DENGAN HUKUM DALAM KASUS TINDAK PIDANA PENCURIAN (STUDI \\ KASUS PENGADILAN NEGERI SIBOLGA NOMOR 2/PID/SUS- ANAK/2016/PN.SBG)
}

\begin{abstract}
Dian Adriawan Dg Tawang
(Dosen Fakultas Hukum Universitas Tarumanagara. Meraih Sarjana Hukum pada Fakultas Hukum Universitas Hassanudin, Magister Hukum pada Fakultas Hukum Universitas Hassanudin, Doktor (Dr.) pada Fakultas Hukum Universitas Hassanudin)

(E-mail: dianadriawan@fh.untar.ac.id)

Mikenda Adiputra Tumanggor

(Mahasiswa Program S1 Fakultas Hukum Universitas Tarumanagara)
\end{abstract}

Received: 22 April 2019; Accepted: 29 Mei 2019; Published: 10 Juni 2019

\begin{abstract}
The constitution Number 11 of 2012 concerning the criminal system of children article 1 pharagraph 7 explain that diversion is the transfer of settlement of child cases and criminal justices proccess to proccess other than criminal. The intended application of diversion effort to children in conflict with the law in criminal case against No.2/PID/Su/2017. The method carried out the another after conducting research is a normative method with interviews. Diversion is a case settlement in a crimw, cartied out by a child and resolved outside the court proccess. The constitution not only provides facilities but required to be completed outside the constitution especially before the trial proccess. This matter in clause 5 pharagraph 3 is strengthened in article 7 pharagraph 1. It seems that the problems of the research have not fully carried out special attention from low enfources in realizing what was written in the constitution. In this cases, it is expected for low enforces to give more attention and considering the best interests of children in handling child criminal cases.
\end{abstract}

Keywords: Child, Juvebile Criminal Justice System, Diversion

\section{PENDAHULUAN}

\section{A. Latar Belakang}

Manusia memiliki ikatan sosial dengan yang lainnya sehingga terciptalah sebuah kepentingan-kepentingan yang muncul didalamnya. Agar tidak terjadi konflik maka diperlukan hukum untuk mengatur hubungan tersebut. Dari tulisan tersebut 
dapat diartikan bahwa hukum lahir dari adanya hubungan antar orangperorangan (masyarakat).

Salah satu pengertian hukum publik yakni suatu norma yang mengatur tentang perbuatan yang dianggap sebagai bentuk pertentangan dan kejahatankejahatan terhadap kepentingan masyarakat, perbuatan mana yang diancam dengan sanksi dimana hal tersebut bagian dari suatu penderitaan atau siksaan. ${ }^{1)}$ Hukum pidana di Indonesia dibagi menjadi 2 (dua) macam yaitu, hukum publik umum yang berasal dari Kitab Undang-Undang Hukum Pidana dan hukum pidana yang pengaturannya diatur secara khusus dalam hal ini biasanya berbentuk undang-undang yang peraturan itu mengatur mengenai tindak pidana terhadap subjek yang khusus yang sumbernya berasal dari luar Kitab Undang-Undang Hukum Pidana. ${ }^{2)}$

Fungsi atau kegunaan dari bentuk hukum pidana pada umumnya adalah sebagai pengaturan kehidupan kemasyarakatan. Andi Hamzah menyatakan bahwa hukum pidana artinya kode moral dalam suatu bentuk bangsa. Sehingga dapat diartikan bahwa perbuatan itu ada yang seharusnya tidak dilakukan, dan ada yang harus dilakukan dalam suatu masyarakat atau negara. Ada beberapa tujuan hukum pidana, yaitu: ${ }^{3)}$

a. Yang pertama adalah untuk memberikan reaksi kepada orang agar tidak melakukan perbuatan pidana, baik untuk:

\section{Memberiekan ketakutan pada semua orang (generale preventie)}

1 ) C.S.T. Kansil dan Christine S.T. Kansil, Latihan Ujian: Hukum Pidana Untuk Perguruan Tinggi., (Jakarta: Sinar Grafika, 2010)., 2.
2) Liza Agnesta Krisna, Hukum Perlindungan Anak: Panduan Memahami Anak yang Berkonflik dengan Hukum, (Yogyakarta: Budi Utama, 2018)., 2.

3) Didik Endro Purwoleksono, Hukum Pidana, (Surabaya: Airlangga University Press, 2016)., 67 . 
2. Menakuti sebagian orang yang telah melakukan pertentangan agar di lain waktu tidak berbuat lagii (speciale preventie)

b. Yang kedua adalah untuk memperbaiki orang-orang yang sudah terlanjut melakukan supaya menjadi orang baik.

Apabila ditarik kesimpulannya, maka dapat dikatakan bahwa hukum pidana ada yang dituju yaitu untuk menanggulangi dan mengurangi atau mencegah suatu tindak kejahatan. Kejahatan sekarang ini sering terjadi di mana saja. Mulai dari kejahatan biasa sampai dengan kejahatan luar biasa. pengertian kejahatan adalah suatu tingkah laku manusia yang tidak tepat dengan kedasaran nilai yang hidup yang telah disahkan oleh hukum tertulis. Kejahatan pada dasarnya merupakan bentuk rumusan mengenai tingkah laku seorang manusia yang diciptakan pihak berwenang pada suatu sekumpulan masyarkat yang secara politis dikatakan bahwa terorganisasi serta merupakan rumusan dari bentuk tindakan yang diberikan kepada seseorang dari orang lain, sehingga kejahatan adalah sesuatu yang diciptakan. ${ }^{4)}$

Dewasa ini, banyak sekali ditemukan pelanggaran ataupun kejahatan yang marak terjadi di kalangan masyarakat. Suatu kejahatan tidak saja dilakukan oleh orang dewasa saja, tapi juga sering dilakukan oleh seorang yang dibawah umur. Seorang yang berfisik muda merupakan amanah dari Sang Ilahi yang memiliki kedudukan istimewa yang harus ditinggikan derajatnya dimana seorang yang berfisik muda ini mempunyai suatu peran yang penting di masa depan yaitu untuk memimpin dan memajukan bangsa Indonesia untuk itu kehidupan harus dijamin oleh orang tua, masyarakat dan bahkan pemerintah. Negara berkewajiban

\footnotetext{
${ }^{4)}$ Richard Quinney berpendapat dalam buku yang ditulis Yesmil Anwar, Kriminologi, (Bandung: Refika Aditama, 2013)., 178.
} 
untuk menjamin bagian anak atas kelangsungan masa depannya, tumbuh dan kembangnya, hak atas perlindungan dari kekerasan serta perbedaan perlakuan. Akan tetapi, mendidik dan membentuk karakter anak bukanlah perkara yang mudah. Karena akibat dari pengaruh lingkungan dan perkembangan zaman yang mempengaruhi pertumbuhan dan psikologis anak menjadi terganggu. Saat ini banyak perilaku anak yang terlihat menyimpang dan dianggap sebagai bentuk dari kenakalan anak.

Definisi anak nakal adalah seorang yang belum dewasa yang dianggap melakukan perbuatan dan dinyatakan suatu bentuk dari perbuatan yang bertentangan, baik menurut peraturan perundangundangan maupun menurut peraturan hukum lainnya yang yang hidup dan berkembang di dalam masyarakat. ${ }^{5}$ ) Kenakalan

5) Angger Sigit Pramukti \& Fuady Primaharsya, Sistem Peradilan Pidana Anak, (Yogyakarta: Medpress. 2014)., 40. anak diambil dari istilah juvenale delinquency, namun kenakalan dalam hal tersebut tidak berarti dari Pasal 489 Kitab UndangUndang Hukum Pidana. Definisi dari pengertian juvenale delinquency berkembang dari istilah juvenale artinya young atau muda, sifat khas pada periode remaja; sedangkan dalam hal ini delincuency adalah wrong doing, terabaikan/mengabaikan, yang pada intinya diperluas menjadi jahat, a-sosial, kriminal, pelanggaran aturan, pembuat ribut, pengacau, peneror, tidak bisa diperbaiki lagi, durjana, dursila, dan lain-lain. ${ }^{\text {) }}$

Terdapat dua pengelompokkan tingkah laku anak yang membuat seorang anak berhadapan dengan hukum yakni status offender dan juvenile delinquency. Status offender adalah suatu tindakan anak nakal yang apabila dilakukan orang dewasa bukan dikatakan sebagai suatu kejahatan. Misalnya

\footnotetext{
${ }^{6)}$ Liza Agnesta, Op. Cit., 33.
} 
tidak menuruti orang tua, tidak masuk sekolah, dan melarikan diri. Sedangkan juvenile delinquency adalah tingkah laku kenakalan anak apabila dilakukan orang dewasa dapat dikatakan sebagai suatu kejahatan. ${ }^{7)}$

Kepedulian Negara terhadap anak dapat dilihat dari bentuk pengaturan yang tersusun dalam regulasi-regulasi yang ada. Kenakalan anak diatur dalam Undang-Undang Nomor 11 Tahun 2012 tentang Sistem Peradilan Pidana Anak. Pengertian anak kembali diperluas dan lebih condong dalam pemaknaan anak dalam sistem persidangan pidana anak yaitu anak yang bertatapan dengan hukum, anak yang bermasalah dengan hukum, anak yang menjadi korban, dan anak menjadi saksi, hal ini juga tidak terlepas dengan adanya UndangUndang Nomor 13 Tahun 2006 tentang Perlindungan Saksi dan
Korban sehingga mempengaruhi defenisi anak dalam UndangUndang No. 11 Tahun 2012 tentang Sistem Peradilan Pidana Anak. ${ }^{8)}$

Makna anak berkonflik dengan hukum dapat diartikan sebagai anak yang sudah berusia antara dua belas tahun sampai delapan belas tahun yang dikirakira telah berbuat perbuatan tercela. ${ }^{9)}$ Undang-undang No. 11 Tahun 2012 tentang Sistem Peradilan Pidana Anak mengartikan bahwa anak dibawah umur yaitu sebagai anak yang berkisaran dua belas sampai kurang dari delapan belas tahun, dan anak yang tersangkut dalam perbuatan pidana dibagi dalam tiga kategori:

a. Anak sebagai pelaku tindak pidana (Pasal 1 angka 3 Undang-Undang No. 11 Tahun 2012 tentang Sistem Peradilan Pidana Anak);

${ }^{7)}$ Hari Harjanto Setiawan, Reintegrasi: Praktek Pekerjaan Sosial Dengan Anak Yang Berkonflik Dengan hukum, (Yogyakarta: Budi Utama, 2018)., 122.

\footnotetext{
${ }^{8)}$ Ibid., 41.

9) Ibid., 42.
} 
b. Anak sebagai korban tindak pidana (Anak Korban) (Pasal 1 angka 4 Undang-Undang No. 11 Tahun 2012 tentang Sistem Peradilan Pidana Anak); dan

c. Anak sebagai saksi tindak pidana (Anak Saksi) (Pasal 1 angka 5 Undang-Undang No.

11 Tahun 2012 tentang Sistem Peradilan Pidana Anak)

Pasal 1 angka 7 UndangUndang No. 11 Tahun 2012 tentang Sistem Peradilan Pidana Anak menegaskan bahwa diversi itu proses pemindahan kasus si muda dari proses penyelesaian di dalam persidangan ke proses penyelesaian di luar persidangan. Adapun tujuan diadakannya diversi pada seorang anak antara lain adalah untuk menghindari proses pembatasan terhadap anak dan pelabelan anak sebagai penjahat dan anak dimasudkan untuk bertanggungjawab atas perbuatan yang tercelanya. ${ }^{10)}$

Jika dikaitkan dengan International Covenant on Civil and Political Rights (ICCPR), terdapat istilah Kovenan yang pada dasarnya mengatur mengenai apa yang diperoleh dalam diri. Hal itu sebenarnya tegas diakui akan tetapi dalam implementasinya wajib difokuskan pada yang diterima oleh orang lain dan suasananya memungkinkan untuk melakukan mengenai apa yang diterima tersebut. Fungsi dan tujuan dari dibentuknya Kovenan tersebut pada dasarnya guna menjamin terisinya segala bagian yang diberikan negara, yang artinya akan mendapatkan bagian yang seimbang, serta dapat menikmati bagian tanpa ada tekanan. Diluarnya, Kovenan adalah bentuk penghormatan umum dalam implementasi kebebasan seseorang

10 ) Paulus Hadisuprapto, Delikuensi Anak Pemahaman dan Penanggulangannya, (Malang: Bayu Media Publishing, 2008)., 19. 
dan apa yang diperolehnya dalam diri. $^{11)}$

Salah satu kaidah umum dalam Pasal 26 Kovenan tidak ada perbedaan tingkatan yang mencolok di mata hukum, terlepas dari perbedaan perlakuan dengan sesama dalam memperoleh perlindungan hukum. Sehingga, suatu hukum harus melarang segala bentuk perbedaan perlakuan yang didasarkan pada suatu yang berbeda dari tiap-tiap orang. ${ }^{12}$ ) Dalam Pasal 9 dan Pasal 10 Kovenan menegaskan bahwa setiap orang memiliki kebebasan atas hidupnya. Mengenai seseorang yang dijerat karena rnelaksanakan suatu bentuk kejahatan, jadi kepadanya wajib dibacakan bentuk tuntutan, alasan penahanan, serta hak-haknya, sekaligus kepadanya berhak mendapatkan pengadilan yang seadil-adilnya. Setiap orang yang sedang ditahan berhak

11) Anonim, "Deklarasi Universal Hak-Hak Asasi Manusia”, International Law Making, Volume 4 No. 1 Tahun 2006., 147.

${ }^{12)}$ Ibid., 150. rnendapatkan suatu perlakuan yang sesuai dengan kemanusiaan dan dihormati segala hak asasinya. ${ }^{13)}$

Berkaitan konvensi tersebut, anak merupakan setiap orang dibawah umur yang ditetapkan undang-undang pada seorang yang masih muda (Pasal 1). Dalam hal konvensi tersebut menjelaskan mengenai hal mendasar yang wajib diberikan kepada seorang anak, serta mengatur suatu negara pihak dari Konvensi menetapkan bentuk aturan regulasi guna memberikan terhadap anak hak-hak yang menjadi miliknya pribadi. Pengakuan hak-hak tersebut wajib dilaksanakan tanpa disertai dengan adanya perbedaan perlakuan apapun dan negara pihak juga harus guna mengambil tahap-tahap dalam hal memastikan anak-anak terlindungi dari segala macam bentuk yang tidak diinginkan (Pasal 2). Konvensi menegaskan mengenai bentuk perlakuan yang wajib dilaksanakan berkaitan 
dengan hal utama untuk anak (best ineterest of the child) (Pasal 3 ayat (1)). Lalu, Konvensi menekankan pihak di luar Indonesia dapat menjamin tersedianya perlindungan dan perawatan demi kelayakan dari hidup anak tersebut harus sesuai dengan standar yang ditetapkan oleh yang badan yang bersangkutan (Pasal 3 ayat (2) dan ayat (3)). Selain itu, Konvensi ini juga sangat memperhatikan keadaan yang mempengaruhi pertumbuhan dan perkembangan anak. $^{14)}$

Dalam mengimplementasikan upaya bentuk diversi, terdapat suatu badan yang dikenal dengan sebutan Balai Permasyarakatan yang bertujuan menjalankan tugas serta fungsinya melakukan observasi di dalam masyarakat, melakukan pembimbingan, pengawasan, dan mendampingi anak yang berkonflik dengan hukum. Balai Permasyarakatan atau biasa dikenal dengan istilah

14) Ibid., 163.
Balai Permasyarakatan merupakan suatu unit pelaksanaan dalam hal teknis pada bidang Pembinaan diluar Lembaga Permasyarakatan yang tingkatannya dibawah dan bertanggung jawab terhadap Kepala Kantor Wilayah Departemen Kehakiman. Pada lingkungan peradilan kepada seorang anak yang melakukan kejahatan, Balai Permasyarakatan berfungsi membuat hasil Laporan Penelitian Kemasyarakatan terhadap terdakwa anak adalah sangat penting, karena dengan Laporan Penelitian Kemasyarakatan tersebut, hakim akan mendapatkan gambaran yang sangat jelas mengenai keadaan yang sebenarnya tentang latar belakang anak yang melakukan kejahatan dan penyebab lain atas dilakukannya tindak pidana tersebut.

Penelitian kemasyarakatan oleh balai kemasyarakatan diperuntukan sebagai salah satu bahan pertimbangan Hakim di dalam menjatuhkan putusanya 
terhadap anak berkaitan dengan

pembinaannya. Hal ini diperjelas dalam peraturan Menteri

Kehakiman Republik Indonesia

Nomor: M.03-UM.01.06 Tahun

1991 tentang Perubahan Pasal 12

ayat (2) Permen Keh RI Nomor

M.06-UM.01.06 Tahun 1983

tentang Tata Tertib Persidangan dan Tata Ruang Sidang untuk membuat Laporan Penelitian Kemasyarakatan terhadap terdakwa anak yang dipermasalahakan bukanlah kepada perbaikan keadaan dari anak dikemudian hari agar menjadi lebih baik. Sehingga, balai permasyarakatan memiliki fungsi yang sangat besar dan berdampak pada anak yang diajukan kepersidangan sehubungan penelitian masyarakat yang dibuatnya dan atas kebijakan hakim petugas badan permasyarakatan dapat diminta penjelasan penelitian masyarakat yang dibuatnya. ${ }^{15)}$

${ }^{15)}$ Dina Anggraini, "Fungsi Penelitian
Upaya penerapan diversi yang seharusnya dilakukan masih saja ditemukan berbagai permasalahan, walaupun kepastian hukum yang diberikan oleh negara telah ada. Hal ini dapat dilihat dari banyak masalah terhadap penanganan anak yang bermasalah dengan hukum yang mana belom menerapkan upaya diversi. Salah satu contoh masalah diversi yang penulis teliti yaitu berkaitan dengan Putusan Nomor 2/Pid/SusAnak/2016/PN.Sbg.

Selasa tanggal 19 Januari 2016 bertempat di daerah kota Sibolga telah terjadi tindak pidana pencurian yang dilakukan beberapa orang, salah satunya adalah seorang anak. Anak yang masih berumur 16 tahun ini telah melakukan suatu bentuk tindakan atau perbuatan pidana pencurian dengan upaya mengambil secara dengan paksa suatu barang

Kemasyarakatan Dari BAPAS Anak Dalam Hubungannya Dengan Putusan Hakim Pengadilan Anak Di Pengadilan Nnegeri Pontianak", Gloria Yuris Jurnal Hukum, Volume 4 No. 2 Tahun 2016., 1. 
kepunyaan orang lain dengan tujuan guna memiliki atau menguasai barang hasil curiannya. Perbuatan ini dilakukan bersamasama dengan temannya pada waktu malam hari. Para pelaku terlebih dahulu merusak pintu gereja yang berada di sebelah rumah korban. Pada saat kejadian, pemilik rumah sedang tidur dan tidak mengetahui bahwa para pelaku telah masuk ke dalam rumahnya dan menjalankan aksi pencurian. Setelah selesai menjarah barang korban, para pelaku langsung meninggalkan rumah dan segera pergi. Setelah berselang beberapa hari kejadian tersebut, polisi langsung melaksanakan pencarian dan berhasil menangkap sebagian dari para pelaku dan salah satunya yakni anak yang berumur 16 tahun. Pada kasus tersebut, anak sebagai pelaku tindak pidana terbukti telah melaksanakan tindakan yang bertentangan dengan Pasal 363 Ayat (1) ke-3,4,5 Kitab UndangUndang Hukum Pidana serta di vonis pidana penjara selama 7 bulan oleh Pengadilan Negeri Sibolga pada Putusan Nomor 2/Pid/SUS-ANAK/2016/PN.Sbg.

Anak berbeda dengan orang dewasa dan penanganannya pun wajib dibedakan terhadap narapidana dewasa, hal ini jelas sangat mempengaruhi mental, fisik, dan sosial terhadap anak yang diduga melaksanakan perbuatan pidana. Secara tegas memang kita harus mengupayakan agar seorang anak tidak dipidana, karena tentunya hal tersebut sangat bertentangan juga dengan ultimum remedium dan diversi.

Pada kasus diatas penulis melihat ada kesalahan dalam tahap proses mengakhiri permasalahan anak yang sedang berkonflik dengan hukum, dalam hal ini tidak terdapat suatu upaya diversi yang dilaksanakan terlebih dahulu terhadap beberapa para penegak hukum. Dalam peraturan perundang-undangan telah disebutkan bahwa wajib terlebih dahulu dilakukan upaya diversi sebelum masuk dalam ranah 
pengadilan sebagaimana telah ditegaskan di dalam Pasal 5 ayat (3) Undang-Undang No. 11 Tahun 2012 tentang Sistem Peradilan Pidana Anak. Selain itu perundang-undangan ini juga menegaskan di dalam Pasal 7 ayat (1) yang menyatakan secara tegas bahwa pada tingkat penyidikan, penuntutan, dan pemeriksaan perkara anak di pengadilan negeri wajib melakukan upaya diversi dalam penyelesaian perkara anak yang berhadapan dengan hukum.

Berdasarkan pada latar belakang tersebut, Penulis tertarik untuk melakukan kajian lebih lanjut secara komperehensif dan menuangkannya dalam penulisan skripsi yang berjudul "Penerapan Diversi Terhadap Anak Yang Berhadapan Dengan Hukum Dalam Kasus Tindak Pidana Pencurian Putusan Nomor 2/Pid/SUS-ANAK/2016/PN.Sbg”.

\section{B. Perumusan Masalah}

Bagaimana penerapan upaya diversi bagi anak yang berkonflik dengan hukum pada kasus tindak pidana pencurian dalam Putusan Nomor. 2/Pid/Sus-Anak/2016/PN. Sbg?

\section{PEMBAHASAN}

A. Analisis Penerapan Diversi Terhadap Anak Yang Berkonflik Dengan Hukum Dalam Kasus Tindak Pidana Pencurian Pada Putusan Nomor 2/Pid/Sus-Anak/2016/PN.Sbg

Di dalam penelitian ini, peneliti akan mencoba mengkaji dari berbagai sisi baik dalam asas, prinsip, norma dalam UndangUndang Nomor 11 Tahun 2012 tentang Sistem Peradilan Pidana Anak Jo. Undang-Undang nomor 35 Tahun 2014 tentang Perubahan Atas Undang-Undang Nomor 23 Tahun 2002 tentang Perlindungan Anak Jo. Putusan Pengadilan Negeri Sibolga Nomor 2/Pid/SusAnak/2016/PN.Sbg. Dalam Putusan Pengadilan Negeri Sibolga Nomor: 2/Pid/SusAnak/2016/PN.Sbg dimana seorang Hakim telah menjatuhkan 
vonis/hukuman pidana penjara terhadap seorang anak yang berhadapan dengan hukum.

Putusan ini telah bersifat tetap atau yang dikenal dengan istilah kata lain yaitu inkrah yang berarti telah berkekuatan hukum tetap.

Anak didampingi oleh Penasehat Hukum Jusniar Endah Siahaan, SH. Penasehat Hukum dari Lembaga Bantuan Hukum LBH Suara Rakyat Tapanuli berdasarkan Penetapat Penunjukan Nomor 2/Pid-SusAnak/2016/PN/Sbg tanggal 12 Febuari 2016. Anak juga didampingi oleh perwakilan dari Lembaga Kemasyarakatan dan Orangtua. Dalam proses ini, Penuntut Umum telah mengajukan tuntutan yang pada pokonya terdiri sebagai berikut:

1. Menyatakan anak secara benar menurut hukum melakukan "Pencurian dengan pemberatan" melanggar Pasal 363 ayat (1) ke-3, ke-4 dan ke5 Kitab Undang-Undang
Hukum Pidana sebagaimana dalam dakwaan tunggal.

2. Menjatuhkan pidana penjara kepada anak tersebut oleh karena itu dengan pidana penjara selama 1 (satu) tahun dikurangi selama terdakwa ditahan dengan perintah agar terdakwa tetap ditahan.

Pada kasus ini penuntut umum menilai bahwa anak yang Berhadapan dengan Hukum ini telah melakukan suatu tindak pidana yang meyakinkan para penuntut umum untuk mengajukan tuntututan sebagaimana telah tertulis pada surat tuntutan dan berharap hakim akan menjatuhi hukuman sesuai dengan isi tuntutan. Melihat hal tersebut, anak harus menerima tuntutan yang diajukan oleh Penuntut Umum dalam proses persidangan. Terhadap tuntutan yang diajukan oleh Penuntut Umum, Hakim menerima tuntutan dan mempelajari kasus tersebut sehingga melahirkan 
pertimbangan-pertimbangan

sebagai berikut:

1. Hakim berkeyakinan jika anak/pelaku tindak pidana sudah memperoleh unsurunsur yang terdapat Pasal 363 ayat (1) ke 3,4,5 Kitab Undang-Undang Hukum Pidana.

2. Dalam proses pemeriksaan di persidangan hakim melihat bahwa anak telah benar melakukan perbuatan pidana pencurian dengann cara memasuki halaman orang lain dengan cara paksa.

3. Hakim berkeyakinan bahwa apa yang menjadi isi putusan yang dijatuhi telah sesuai dengan apa yang menjadi perbuatan pelaku tindak pidana, dalam hal ini bagi anak.

Dalam putusan ini, proses persidangan dipimpin oleh seorang hakim yang bernama Marolop Winner P. Bakara, S.H dan dibantu oleh seorang Panitera Pengganti yakni Punia Hutabarat, S.H. sampai dengan proses persidangan selesai. Sidang bersifat tertutup untuk umum karena pelaku tindak pidana adalah seorang anak. Hakim telah menjatuhkan hukuman pidana penjara terhadap Anak yang Berhadapan dengan Hukum dengan pidana penjara selama 7 (tujuh) bulan dan menetapkan bahwa anak akan tetap ditahan. Dari berbagai pertimbangan diatas, Hakim berkeyakinan bahwa telah tepat kiranya dalam menjatuhan hukuman pidana penjara terhadap anak sebagai pelaku tindak pidana tersebut. Hakim melihat dengan hasil akhir yang dijatuhkan dalam putusan ini maka keadilan bagi pelaku ataupun pihak korban telah ditegakkan.

Pada dasarnya, kita telah mengetahui bahwa anak merupakan bagian penting dalam keberlangsungan hidup manusia. Dimana diketahui bahwa anak adalah penerus keturunan keluarga dalam lingkungan sosial masyarakat. Tidak hanya itu, anak 
juga memiliki peran yang sangat penting dalam meneruskan perjuangan bangsa dan negara. Masa depan negara berada ditangan anak-anak bangsa Indonesia, mereka diyakini akan menjadi penerus keberlangsungan kemajuan bangsa ini. Pentingnya peran Anak dalam keberlangsungan negara dapat terlihat dari berbagai regulasi ataupun Peraturan Perundangundangan yang kita miliki. Kepedulian Negara ini muncul akibat dari pentingnya peran anakanak dalam melanjutkan dan memajukan negara ini. Kepedulian-kepedulian tersebut dapat terlihat dari berbagai macam regulasi yang kita miliki saat ini. Misalkan dalam Pasal 28B Ayat (2) Undang-Undang Dasar Negara Republik Indonesia Tahun 1945 menegaskan setiap anak berhak atas kelangsungan hidup, tumbuh, dan berkembangan serta berhak atas perlindungan kekerasan dan perbedaan perlakuan. Dengan adanya penjaminan kesejahteraan anak seperti yang tertuang dalam undang-undang tersebut maka negara, lembaga-lembaga, masyarakat, dan orangtua wajib turut serta dalam menjamin dan menjaga pertumbuhan anak agar dapat menjadi anak yang baik dan berguna untuk memajukan negara. Dengan adanya penjaminan perlindungan terhadap anak, maka seharusnya dalam keberlangsungan hidup anak mendapatkan perlakukan yang layak sepertimana telah tercantum dalam Undangundang.

Selain itu anak juga harus mendapatkan perlindungan khusus, sebab mengingat bahwa anak tidak dapat dipersamakan dengan orang dewasa. Dalam Pasal 1 angka 2 Undang-Undang Nomor 35 tentang Perubahan Atas UndangUndang Nomor 23 Tahun 2002 tentang Perlindungan anak telah jelas menegaskan perlindungan anak itu suatu bentuk kegiatan untuk menjamin dan melindungi anak dan hak-hak anak untuk dapat hidup, tumbuh, berkembang, dan 
berpartisipasi secara maksimal sesuai dengan harkat dan martabat kemanusiaan, serta mendapatkan perlindungan dari kekerasan dan pembedaan perlakuan terhadap sesama. Melihat penjelasan tersebut, maka terhadap anak perlu diberikan perhatian khusus dan juga perlindungan khusus, sebab anak dianggap tidak dapat memperjuangkan hak-haknya sendiri tanpa adanya bantuan orang lain.

Dalam Pasal 1 angka 2 Undang-Undang Nomor 11 Tahun 2012 tentang Sistem Peradilan Pidana Anak menegaskan Anak yang Berhadapan dengan Hukum adalah Anak yang berkonflik dengan hukum, anak yang menjadi korban tindak pidana, dan anak yang menjadi saksi tindak pidana. Terlihat pada kalimat diatas bahwa ada perbedaan antara anak yang berkonflik dengan hukum, anak yang menjadi korban tindak pidana, dan anak yang menjadi saksi tindak pidana. Terhadap anak yang berkonflik dengan hukum telah ditegaskan Pasal 1 angka 3 Undang-Undang Nomor 11 Tahun 2012 tentang Sistem Peradilan Pidana Anak anak yang telah berusia 12 (dua belas) tahun, tetapi belum berusia 18 tahun yang disangka melakukan perbuatan pidana. Anak yang Menjadi Korban Tindak Pidana adalah anak yang belum berusia 18 tahun yang mengalami penderitaan jiwa dan raga serta kerugian ekonomi yang disebabkan oleh tindak pidana. Sedangkan Anak yang Menjadi Saksi Tindak Pidana diatur dalam Pasal 1 angka 5 Undang-Undang Nomor 11 Tahun 2012 tentang Sistem Peradilan Pidana Anak menjelaskan Anak yang Menjadi Saksi Tindak Pidana adalah anak yang belum berusia 18 tahun yang mampu memberikan keterangan untuk kepentingan penyidik, penuntut, dan pemeriksaan di sidang pengadilan mengenai suatu perkara pidana yang didengar, dilihat, dan/atau dialami sendiri.

Pada dasarnya undang-undang telah menegaskan bahwa terhadap 
anak wajib diberikan perlindungan

khusus dimana hal ini dilakukan oleh pemerintah sebagaimana telah disebutkan dalam Pasal 59 Ayat 1 Undang-Undang nomor 35 Tahun 2014 tentang Perubahan Atas Undang-Undang Nomor 23 Tahun 2002 tentang Perlindungan Anak. Penjagaan khusus yang dimaksud adalah suatu bentuk perbuatan bagi anak agar supaya anak terjamin dan terhindar dari ancaman bahaya sehingga terjamin kondisinya. Lebih spesifik lagi disebutkan dalam ayat (2) penjagaan khusus itu ditujukan kepada dia yang memiliki kondisi tertentu atau situasi darurat, anak yang berhadapan dengan hukum, anak yang berasal dari kelompok minoritas dan terisolasi, anak eksploitasi secara ekonomi dan/atau seksual, anak korban obat-obatan terlarang dan zat adiktif lainnya, anak korban pornografi, anak penyakitan, anak korban penculikan, penjualan, anak korban kekerasan fisik dan/atau psikis, anak korban pemerkosaan, anak korban jaringan terorisme, anak berkebutuhan, anak korban perlakuan salah dan, anak dengan perilaku sosial yang menyimpang, dan anak korban stigmatisasi dari pelabelan terkait dengan kondisi orangtuanya.

Titik fokus yang penulis analisis yakni pada permasalahan anak yang berhadapan dengan hukum, dan lebih tepatnya pada anak yang berkonflik dengan hukum. Putusan Nomor 2/Pid/SusAnak/2016/PN.Sbg telah menetapkan vonis oleh seorang hakim kepada anak berkonflik pada hukum dalam kasus perbuatan pidana pencurian. Anak berkonflik dengan hukum ini dijatuhi hukuman penjara selama 7 (tujuh) bulan dan dinyatakan harus menjalani hukumannya dengan cara tetap ditahan. Jika dilihat dari sisi prinsip yang utama bagi yang dibawah umur, maka dalam hal penjatuhan pidana penjara yang tertuang dalam putusan tersebut sangat bertentangan. 
Pada dasarnya prinsip yang utama bagi yang dibawah umur untuk menjamin keberlangsungan hidup anak yang lebih baik. Untuk itu prinsip kepentingan terbaik baik bagi anak sangat perlu menjadi pusat perhatian dalam menangani perilaku anak yang menyimpang, dan tentu harus dijadikan pertimbangan dalam mengambil keputusan dalam menangani kasus anak yang berhadapan dengan hukum. Sebab diketahui bahwa ketika seorang anak telah dijatuhi hukuman pidana penjara, maka pada saat itu juga hak kemerdekaanya sebagai anak telah dicabut. Anak yang sedang menjalani hukuman penjara akan terpisah dari orangtua, keluarga, teman-teman dan bahkan dunia bermainnya hanya karena menjalani hukuman akibat dari perbuatannya sendiri. Pada fase ini anak akan mengalami perubahan lingkungan, dimana anak yang menjalani hukuman pidana akan kehilangan hangatnya kasih sayang keluarga secara langsung. Dengan keadaan ini, anak yang menjalani pidana penjara akan merasa terasingkan dari anak-anak lain dan akan merasa adanya ketimpangan dari perlakuan masyarakat terhadap dirinya. Bahkan setelah anak keluar dari Lembaga Permasyarakatan akan merasa adanya perlakuan yang berbeda dari masyarakat sekitarnya. Hal ini jelas, karena anak yang telah dijatuhi hukuman penjara akan secara sendirinya melahirkan stigmatisasi dalam masyarakat dimana anak tersebut akan selalu dianggap sebagai seorang pelaku kejahatan (kriminal). Stigmatisasi seperti ini akan tertanam terus dalam pikiran anak tersebut, sehingga dapat merusak psikis/mentalnya. Untuk itu perlunya anak yang berkonflik dengan hukum dihindarkan dari perampasan kemerdekaan dan pemidanaan. Maka sangat perlu memperhatikan prinsip kepentingan bagi anak dijadikan sebagai pertimbangan dalam pengambilan keputusan, karena 
anak adalah generasi penerus yang menentukan masa depan dunia.

Menghindarkan anak yang berkonflik dengan hukum dari proses peradilan sangatlah mungkin untuk dilakukan, mengingat pentingnya peran anak sehingga perlu dilakukannya perlindungan khusus terhadap berlangsungnya kehidupan yang baik serta menjamin dalam kesejahteraan kepada seorang anak. Dalam UU SPPA dikenal istilah diversi. Diversi diketahui sebagai penyelesaian perkara pidana yang dilakukan oleh anak dan diselesaikan diluar proses pengadilan. Undang-undang ini tidak hanya memberikan fasilitas tersebut, melainkan mewajibkannya untuk diupayakan terlebih dahulu sebelum masuk dalam proses penyelesaian dipersidangan. Hal ini ditegaskan dalam Pasal 5 Ayat (3) dan diperkuat lagi dalam Pasal 7 Ayat (1). Untuk itu perlunya perhatian dari para penegak hukum dalam merealisasikan apa yang telah dituangkan dalam pasal tersebut, mengingat juga perlunya menyelamatkan masa depan anakanak. Diversi dianggap dapat menjadi jalan keluar dalam menghadapi perilaku anak yang menyimpang dan dapat merubah perilaku anak menjadi lebih baik. Menurut Ketentuan Umum Pasal 1 angka (7) Undang-Undang Nomor 11 Tahun 2012 tentang Sistem Peradilan Pidana Anak, diversi adalah pengalihan penyelesaian perkara Anak dari proses peradilan pidana ke proses di luar peradilan pidana.

1. Tujuan diversi menurut Pasal 6 Undang-Undang Nomor 11 Tahun 2012 tentang Sistem Peradilan Pidana Anak yakni:

a. Menuju ketentraman antara korban dan anak yang bermasalah;

b. Selesainya kasus anak di luar proses persidangan khusus yang dibuat;

c. mencegah anak dari perampasan kebebasan hidup yang seharusnya; 
d. Mendorong semuanya untuk Bersama-sama bekerjasama; dan

e. Menciptakan kewajiban kepada anak untuk patuh dan melaksanakan apa yang seharusnya.

2. Syarat dapat dilaksanakannya diversi dinyatakan pada Pasal 7 ayat (1 dan 2) UndangUndang Nomor 11 Tahun 2012 tentang Sistem Peradilan Pidana Anak yaitu:

(1) Pada tingkat penyidikan, penuntutan, dan pemeriksaan perkara anak di pengadilan negeri wajib diupayakan diversi.

(2) Diversi sebagaimana dimaksud pada ayat (1) dilaksanakan dalam hal tindak pidana yang dilakukan:

a. Diancam dengan penjatuhan akibat berupa penahanan dibawah tujuh tahun; dan b. Bukan sesuatu perbuatan pidana yang berulang.

Menurut peraturan perundangundangan yang telah disebutkan di atas menyimpulkan bahwa diversi hanya dapat dilakukan apabila ancaman pidananya dibawah 7 (tujuh) tahun dan bukan merupakan perbuatan pidana berulang atau residivis. Dengan kata lain, apabila ancaman hukuman 7 (tujuh) tahun atau lebih dan merupakan seorang residivis tidak dapat diupayakan diversi. Untuk itu sangat perlu perhatian dari para penegak hukum untuk merealisasikan apa yang telah tertuang dalam Undang-undang. Karena kepastian hukum telah diberikan oleh negara, tinggal bagaimana

mengimplementasikannya di dalam masyarakat.

Dalam perkara anak Aidil dalam putusan nomor 2/Pid/SusAnak/2016/PN/Sbg tidak terlihat adanya upaya diversi terlebih dahulu sebagaimana telah diatur 
dalam Undang-undang Sistem

Peradilan Pidana Anak Nomor 11

Tahun 2012 yang menyebutkan

bahwa wajib dilakukan terlebih dahulu. Melihat dari ketentuan diatas bahwa seharusnya anak mendapatkan pengupayaan diversi dulu sebelum dilaksanakan proses peradilan. Namun kenyataannya anak (Aidil) tidak mendapatkan pengupayaan penyelesaian perkara pidana di luar persidangan terlebih dahulu, melainkan langsung ketahap proses peradilan. Akibatnya anak (Aidil) harus terlibat dalam proses peradilan dan mendapatkan vonis hukuman pidana penjara selama 7 bulan.

Dalam penanganan perkara anak (Aidil), penulis melihat ada kesalahan yang dilakukan para penegak hukum pada proses penyelesaian perkara pidana. Penulis berpendapat bahwa para penegak hukum tidak menjalankan apa yang telah menjadi ketentuanketentuan seperti mana telah tertuang dalam Undang-undang yang berlaku. Dimana seharusnya para penegak hukum harus lebih memperhatikan dan memahami isi dari regulasi agar terhindar dari kesalahan-kesalahan seperti dalam hal ini. Selain menjadi kewajiban untuk menjalankan Undangundang dan juga untuk memperhatikan penjaminan masa depan anak yang lebih baik. Mengingat bahwa anak haruslah dilindungi secara khusus karena pentingnya peran anak dalam kehidupan ini.

Banyak manfaat yang bisa diambil dari penerapan diversi baik bagi anak sebagai pelaku kejahatan, korban, dan juga penegak hukum. Manfaat pelaksanaan penerapan program diversi antara lain:

1. Menolong yang muda-muda belajar memperbaiki diri dari kesalahannya

2. Memperbaiki akibat dari perbuatan pidana karena peristiwan yang terjadi tersebut kepada keluarga, korban, dan masyarakat 
3. Membangun hubungan terhadap orang tua, yang mengurusi dan membantu nasehat hidup sehari-hari

4. Memenuhi dan meningkatkan yang muda untuk membuat keputusan yang telah diberikan kepadanya tanpa adanya embel-embel

5. Ngasih tanggungjawab anak atas perbuatannya dan memberikan pelajaran tentang kesempatan mengamati akibat-akibat dan efek dari perbuatannya

6. Mengasih kesempatan bagi pelaku untuk berkesempatan untuk menjaga agar tetap bersih atas catatan kejahatan

7. Mereduksi upaya pada pengadilan dan instansi permasyarakatan

8. Pengendalian kejahatan anak/remaja

Hal-hal ini seharusnya menjadi perhatian bagi para penegak hukum sebelum melimpahkan perkara anak ke dalam proses persidangan. Selain manfaat tersebut, perlu juga memperhatikan keadaan anak, sebab anak diketahui masih belum bisa hidup tanpa campur tangan orang dewasa. Kelangsungan hidup anak sangat bergantung pada orang dewasa, untuk itu perlu dipertimbangakan memisahkan anak dari orangtua dan keluarga. Ketika anak ditempatkan di Lembaga Permasyarakatan maka secara langsung akan memisahkan anak dari keluarga dan orangtuanya.

Diversi juga didalamnya ada yang baik-baik yang bisa diambil dimana berupa keuntungan yang memihak perlindungan Hak Asasi Manusia anak, maka dari itu perlu benar-benar dijalankan dan direspon oleh pihak terkait demi kepentingan semua pihak, yang terpenting untuk yang muda jiwa dan fisiknya. Diharapkan juga peran para penegak hukum untuk selalu berusaha untuk mengupayakan diversi dan berharap untuk dapat memberikan penjelasan kepada pihak korban 
untuk bisa menerima upaya penyelesaikan perkara diluar proses pengadilan. Pentingnya memberikan keterangan atau penjelasan kepada pihak korban agar dapat memahami penyelesaian perkara pidana di luar persidangan karena persetujuan pihak korban sangat mempengaruhi berhasilnya pengupayaan diversi ini. Dalam hal ini, sangat dibutuhkan keahlian para penegak hukum dalam pendekatan pada semua bagian dari para penegak hukum dalam kasus seseorang yang masih muda kelihatannya.

Anak yang berbuat suatu tindak pidana baik itu perbuatan bertentangan ringan ataupun perbuatan pertentangan berat tidaklah selalu menjadi alasan untuk menyeret anak ke dalam proses persidangan dan akhirnya mendapatkan hukuman pidana penjara. Perlu juga mempertimbangkan akibat dari penjatuhan pidana penjara tersebut terhadap psikis, mental dan masa depan anak. Sangat disayangkan apabila masa depan anak akan hilang akibat dari penjatuhan hukuman tersebut. Para penegak hukum haruslah mengutamakan pendekatan keadilan restoratif seperti pada prinsip Undang-Undang Nomor 11 Tahun 2012 tentang Sistem Peradilan Pidana Anak meski menjatuhkan hukuman pidana penjara sebagai pembalasan akibat dari suatu perbuatan.

Pasal 81 Undang-Undang Nomor 11 Tahun 2012 tentang Sistem Peradilan Pidana Anak menyebutkan bahwa pada ayat (1) "anak dikenakan hukuman penjara di Lembaga permasyarakatan khusus anak seandainya kondisi tersebut meresahkan dan berdampak buruk bagi masyarakat". Pada kalimat tersebut telah jelas menyatakan tidak selalu perbuatan pidana oleh seorang anak wajib dijatuhi hukuman pidana penjara. Hanya perbuatan-perbuatan yang dianggap akan membahayakan 
masyarkat yang perlu dilakukan tindakan pemenjaraan. Melihat perkara pidana pada kasus yang penulis jadikan sebagai objek penelitian ini sangatlah mungkin anak akan berubah tanpa harus di penjara. Mengingat anak masih bisa diatur dan diajari oleh kedua orang tua, maka sangat besar kemungkinan anak akan berubah menjadi lebih baik. Pada ayat (5) juga ditegaskan kembali bahwa "upaya terakhir untuk anak adalah dengan memenjarakan anak yang bermasalah" yang berarti masih banyak pengupayaanpengupayaan lain yang bisa dijadikan alat untuk merubah perilaku seorang anak. Pidana penjara bukanlah jawaban dari permasalahan penanganan perkara anak, melainkan tindakan itu sebagai pengupayaan terakhir. Penulis juga sependapat dengan Hakim Anak yang menyatakan, pada prinsipnya bahwa pidana penjara adalah bertujuan untuk memperbaiki sikap para pelaku tindak pidana. Pidana penjara sebenarnya bukan semata-mata untuk pembalasan terhadap apa yang telah dilakukan para pelaku kejahatan, melainkan suatu upaya untuk memperbaiki perilaku yang diharapkan menjadi lebih baik. Akan tetapi ada baiknya sebelum mengambil keputusan penjatuhan pidana penjara terhadap anak, perlu diperhatikan apakah pemidanaan itu akan merubah perilaku anak menjadi lebih baik atau malah sebaliknya bahwa akan menimbulkan perilaku anak menjadi lebih parah. Mengingat bahwa perkembangan anak sangat dipengaruhi oleh faktor lingkungan, karena lingkungan yang baik menjamin pengaruh yang baik juga terhadap perilaku seorang anak. ${ }^{16)}$

Melihat dari sisi teori keadilan, maka sebenarnya penestapaan dan pencelaan terhadap dan bagi yang muda

16) Peneliti, Wawancara, dengan Hakim Anak Pengadilan Negeri Jakarta Pusat Kelas IA Khusus, (Jakarta: Pengadila Negeri Jakarta Pusat, 16 Mei 2019). 
dalam hal ini adalah pelaku perbuatan pidana sangatlah tidak menunjukkan gambar dari bentuk keadilan tersebut. Mengingat anak tidak dapat disamakan dengan orang dewasa maka tidaklah wajar jika anak dijatuhi hukuman pidana penjara. Apalagi adanya upaya penyelesaian perkara pidana diluar proses persidangan sebagaimana telah tercatat dalam undang-undang yang berlaku seharusnya hal-hal demikian dijadikan untuk jalan preses penyelesaian perkara anak.

\section{PENUTUP}

\section{A. Kesimpulan}

Berdasarkan apa yang menjadi permasalahan, dimana kasus pencurian yang dilakukan anak yakni Aidil Fitra Daeli (16) sebagai tersangka anak yang mana tidak mendapatkan upaya diversi terlebih dahulu sebagaimana telah tercantum dalam Undang-Undang Nomor 11 Tahun 2012 tentang Sistem Peradilan Pidana Anak seperti mana diketahui bahwa diversi suatu proses diluar jalur letigasi. Terlebih upaya bentuk diversi itu adalah bentuk kewajiban harus diupayakan dulu sebelum proses peradilan. Penulis melihat masih kurangnya perhatian khusus oleh penegak hukum. Tidak diketahui apakah hal ini diakibatkan karena kelemahan para penegak hukum atau kelalaian dalam mengaplikasikan apa yang menjadi isi dalam Peraturan Perundang-undangan. Kurangnya pengawasan dari pihak pengawas terhadap para penegak hukum juga sangat mempengaruhi terealisasikannya suatu aturan hukum, sehingga perlu ditingkatkan lagi dari sisi pengawasan agar tidak terjadi kembali kesalahan seperti dalam kasus penelitian ini. Untuk itu perlu meningkatkan perhatian perhatian khusus dalam menangani perkara pidana anak karena hal ini menyangkut masa depan anak yang lebih baik.

Pada dasarnya prinsip kepentingan yang utama dan 
terbaik bagi anak adalah untuk menjamin keberlangsungan hidup anak yang lebih baik. Untuk itu prinsip kepentingan terbaik baik bagi anak sangat perlu menjadi pusat perhatian dalam menangani perilaku anak yang menyimpang, dan tentu harus dijadikan pertimbangan dalam mengambil keputusan dalam menangani perkara anak yang berhadapan dengan hukum. Sebab diketahui bahwa ketika seorang anak telah dijatuhi hukuman pidana penjara, maka pada saat itu juga hak kemerdekaanya sebagai anak telah dicabut. Anak yang sedang menjalani hukuman penjara akan terpisah dari orangtua, keluarga, teman-teman dan bahkan dunia bermainnya hanya karena menjalani hukuman akibat dari perbuatannya sendiri.

Pada fase ini anak akan mengalami perubahan lingkungan, dimana anak yang menjalani hukuman pidana akan kehilangan hangatnya kasih sayang keluarga secara langsung. Dengan keadaan ini, anak yang menjalani pidana penjara akan merasa terasingkan dari anak-anak lain dan akan merasa adanya ketimpangan dari perlakuan masyarakat terhadap dirinya. Bahkan setelah anak keluar dari Lembaga Permasyarakatan akan merasa adanya perlakuan yang berbeda dari masyarakat sekitarnya. Hal ini jelas, karena anak yang telah dijatuhi hukuman penjara akan secara sendirinya melahirkan stigmatisasi dalam masyarakat dimana anak tersebut akan selalu dianggap sebagai seorang pelaku kejahatan (kriminal).

Stigmatisasi seperti ini akan tertanam terus dalam pikiran anak tersebut, sehingga dapat merusak psikis/mentalnya. Untuk itu perlunya anak yang berkonflik dengan hukum dihindarkan dari perampasan kemerdekaan dan pemidanaan. Maka sangat perlu memperhatikan prinsip yang diutamakan bagi anak dijadikan sebagai pertimbangan dalam pengambilan keputusan, karena 
anak adalah generasi penerus yang

menentukan masa depan dunia.

\section{B. Saran}

1. Bagi Penegak Hukum, agar lebih memperhatikan hal-hal apa yang menjadi isi dari Peraturan Perundangundangan. Penyidik, Penuntut Umum, Hakim, dan Lembagalembaga pemerintahan yang terkait dalam pengupayaan diversi harus benar-benar merealisasikan isi daripada regulasi tersebut. Agar kepastian hukum yang diberikan oleh Negara terhadap masyarakat dapat dirasakan sepenuhnya. Selain untuk mendapatkan kepastian hukum perlu memperhatikan keadilan bagi yang merasa dirugikan, baik si yang melakukan dan juga bagi dia yang merasa dirugikan akibat dari perbuatan si pembuat.

2. Bagi masyarakat, diharapkan agar peran masyarakat lebih aktif lagi dalam menggunakan upaya diversi dalam menyelesaikan perkara pidana anak yang ada. Karena peran masyarakat secara tidak langsung memiliki dampak yang besar terhadap penyelesaian perkara pidana anak. Tanpa peran mereka maka upaya khusus penyelesaian perkara bagi anak tidak akan bergerak. Selain berperan untuk melaksanakan diversi, masyarakat juga perlu melakukan pengawasan terhadap para penegak hukum agar tidak terjadi kesalahankesalahan dalam mengimplementasikan

Undang-undang.

3. Bagi keluarga, tentunya kita ketahui bahwa peran keluarga didalam mendidik anak sangatlah berpengaruh bagi kepentingan mental, fisik, sosial bagi seorang anak, oleh karena itu diharapkan supaya keluarga terutama seluruh orang tua lebih memantau lagi 
keadaan seorang anak agar dapat mencegah terjadinya hal yang menyimpang dari seorang anak. Salah satu caranya adalah dengan melakukan pendekatan secara internal di dalam ikatan antara anak dengan orang tua.

IV. DAFTAR PUSTAKA

\section{A. Buku}

Anwar, Yesmil. Kriminologi. Bandung: Refika Aditama, 2013.

Hadisuprapto, Paulus. Delikuensi

Anak Pemahaman dan

Penanggulangannya.

Malang: Bayu Media

Publishing. 2008.

Kansil, C.S.T. dan Christine S.T.

Kansil. Latihan Ujian:

Hukum Pidana Untuk

Perguruan Tinggi.

Jakarta: Sinar Grafika. 2010.

Krisna, Liza Agnesta. Hukum Perlindungan Anak: Panduan Memahami Anak yang Berkonflik dengan

Hukum.

Yogyakarta:

Budi

Utama. 2018.

Muryati, Kun dan Juju Suryawati. Kriminologi. Jakarta: Gelora Aksara Pratama. 2001.

Pramukti, Angger Sigit \& Fuady Primaharsya. Sistem Peradilan Pidana Anak. Yogyakarta: Medpress. 2014.

Purwoleksono, Didik Endro. Hukum Pidana.

Surabaya: Airlangga University Press. 2016.

Setiawan, Hari Harjanto Reintegrasi: Praktek Pekerjaan Sosial Dengan Anak Yang Berkonflik Dengan hukum. Yogyakarta: Budi Utama. 2018.

\section{B.Artikel Jurnal Online}

Anggraini, Dina. "Fungsi Penelitian Kemasyarakatan Dari BAPAS Anak Dalam Hubungannya Dengan Putusan Hakim Pengadilan 
Volume 17, No. 1, Juni 2019

Anak Di Pengadilan

Negeri Pontianak". Gloria

Yuris Jurnal Hukum.

Volume 4 No. 2 Tahun

2016.

Anonim, "Dekiarasi Universal Hak-

Hak Asasi Manusia".

International Law Making.

Volume 4 No. 1 Tahun

2006. 